\title{
Time Course Studies on Impact of Low Temperature Exposure on the Levels of Protein and Enzymes in Fifth Instar Larvae of Eri Silkworm, Philosamia ricini (Lepidoptera: satuniidae)
}

Anita Singh', Vivek Kumar Gupta ${ }^{1}$, Nikhat Jamal Siddiqi ${ }^{3}$, Shaily Tiwari ${ }^{2}$, Anita Gopesh ${ }^{2}$ and Bechan Sharma ${ }^{1 *}$

${ }^{1}$ Department of Biochemistry, University of Allahabad, Allahabad-211001, UP, India

${ }^{2}$ Department of Zoology, University of Allahabad, Allahabad-211001, UP, India

${ }^{3}$ Department of Biochemistry, King Saud University, Riyadh-11495, Saudi Arabia

\begin{abstract}
Lactate dehydrogenase (LDH; EC 1.1.1.27) and malate dehydrogenase (MDH; EC 1.1.1.37) are the enzymes involved in energy metabolism of Eri silkworm, Philosamia ricini. However, no previous study has been reported about effect of low temperature exposure on their levels in different tissues of Eri silkworm. The present study was aimed to the time-course effects of low temperature $\left(\sim 10^{\circ} \mathrm{C}\right)$ exposure of $5^{\text {th }}$ instar $P$. ricini on the levels of protein and energy metabolism enzymes of three major tissues (haemolymph, silk gland and fat body). The Eri silkworm larvae, reared on fresh leaves of castor-oil-plant (Ricinus communis), were divided into 4 groups: a control group reared at $25 \pm 2^{\circ} \mathrm{C}$ along with three experimental groups reared at $10 \pm 1^{\circ} \mathrm{C}$ containing 50 larvae in each, for varying durations $(2,4$ and 7 days). The cell free extract was prepared by centrifuging the tissue homogenate at $9000 \mathrm{~g}$ and used for biochemical estimations (total protein content, lactate dehydrogenase and malate dehydrogenase activities). For isozyme analysis, another set of homogenates $(20 \% \mathrm{w} / \mathrm{v})$ was prepared in buffer $(0.2 \mathrm{M} \mathrm{Tris} \mathrm{HCl}, \mathrm{pH} 7.0)$ containing $0.2 \mathrm{M}$ sucrose and $10 \mathrm{mM}$ EDTA, and analyzed by native-PAGE followed by activity staining. The activities of lactate dehydrogenase and malate dehydrogenase showed significant decrease in haemolymph, whereas in fat bodies both enzymes showed increased activity. In silk gland, Lactate dehydrogenase activity decreased uniformly, whereas malate dehydrogenase activity increased at all exposure durations. The isozyme analysis revealed significant perturbations in their expression profiles. The low temperature exposure resulted into accumulation of protein content in haemolymph and depletion in silk gland and fat body tissues. Fat bodies emerged as the main energy producing organ under this condition. Lactate dehydrogenase and malate dehydrogenase displayed presence of only one isozyme in all the tissues tested. The isozyme behaviour of lactate dehydrogenase and malate dehydrogenase towards low temperature varied in different tissues. These results suggested that alterations in expression and functions of these enzymes might be associated to the acclimation of larvae at low temperature.
\end{abstract}

Keywords: Lactate dehydrogenase; Malate dehydrogenase; Isozyme; Native-PAGE; Eri silkworm; Silk gland and Fat body tissues

Abbreviations: LDH: Lactate Dehydrogenase; MDH: Malate Dehydrogenase;PAGE:PolyacrylamideGelElectrophoresis;EC:Enzyme Commission; NAD: Nicotinamidde Dinucleotide; TCA: Tricarboxylic Acid; APS-Ammonium Persulfate; SE: Standard Error; TBE: TriBorate Buffer; TEMED: N,N,N',N'-Tetramethylethylenediamine; $\mathrm{KCl}$ : Potassium Chloride, NADH: Nicotinamide Adenine Dinucleotide; EDTA: Ethylene Diamine Tetraacetic Acid; NaCl: Sodium Chloride; $\mathrm{CaCl}_{2}$ : Calcium Chloride; FCR: Folin-Ciocalteu Reagent; $\mathrm{CuSO}_{4}$ : Copper Sulphate; $\mathrm{NaOH}$ : Sodium Hydroxide; $\mathrm{HCl}$ : Hydrochloric Acid.

\section{Introduction}

Many insects are ecological (predators) and economically beneficial for example silkworms have been used to produce silk. Insects in their life history are encounter adverse climate conditions, such as scorching heat in summer and terrifying cold in winter season. It is necessary for the insects to evolve corresponding strategies against such adverse conditions to protect themselves [1,2]. Philosamia ricini (eri silkworm), a non-mulberry silkworm, is known to produce the silk with high thermal property, strength and durability. The eri silkworm can be blended with many other materials for textile and non-textile applications. It mainly feeds on castor leaves (Ricinus communis). It has been observed that the quality of host plant and the low temperature exposure may influence the production of silk.

It has been reported that insects display an extraordinary array of adaptations that allow them to sustain metabolic activity during such harsh conditions [3]. A large number of insects usually meet with harsh low temperature in winter season. They change physiologically, biochemically and behaviorally for increasing the capacity of coldhardiness [2,4]. Some studies have been conducted to study the acclimation of various organisms to low temperature and hypoxic conditions in order to understand the role of few intermediary metabolites and enzymes. The enzymes concerned with energy metabolism can be divided into three groups, those related to anaerobic metabolism, aerobic metabolism and the pentose phosphate pathway [5]. However, studies are required to understand the role of energy metabolism enzymes in insects including Eri silkworm exposed to low temperature [6].

There are many important enzymes involved in energy metabolism of insects out of which lactate dehydrogenase ( $\mathrm{LDH}$, lactate; NADoxidoreductase, E.C. 1.1.1.27) and malate dehydrogenase $(\mathrm{MDH}$, L-malate: NAD'-oxidoreductase, E.C. 1.1.1.37) are the most studied.

*Corresponding author: Bechan Sharma, Department of Biochemistry University of Allahabad, Allahabad-211001, UP, India, Tel: +91-9415715639; E-mail: sharmabi@yahoo.com

Received: May 23, 2017; Accepted: June 20, 2017; Published June 23, 2017

Citation: Singh A, Gupta VK, Siddiqi NJ, Tiwari S, Gopesh A, et al. (2017) Time Course Studies on Impact of Low Temperature Exposure on the Levels of Protein and Enzymes in Fifth Instar Larvae of Eri Silkworm, Philosamia ricini (Lepidoptera: satuniidae). Biochem Anal Biochem 6: 321. doi: 10.4172/2161-1009.1000321

Copyright: () 2017 Singh A, et al. This is an open-access article distributed under the terms of the Creative Commons Attribution License, which permits unrestricted use, distribution, and reproduction in any medium, provided the original author and source are credited. 
Citation: Singh A, Gupta VK, Siddiqi NJ, Tiwari S, Gopesh A, et al. (2017) Time Course Studies on Impact of Low Temperature Exposure on the Levels of Protein and Enzymes in Fifth Instar Larvae of Eri Silkworm, Philosamia ricini (Lepidoptera: satuniidae). Biochem Anal Biochem 6: 321. doi: 10.4172/2161-1009.1000321

Page 2 of 6

LDH is one of the enzyme involved in Glycolytic pathway $[5,7,8]$ which catalyses a reversible reduction of pyruvate into lactate using $\mathrm{NADH}$ as a cofactor under anaerobic conditions. MDH is involved in TCA cycle and known to catalyze the reversible oxidation of malate to oxaloacetate requiring $\mathrm{NAD}$ as a cofactor. It is also involved in gluconeogenesis, lipogenesis and in malate-aspartate shuttle during aerobic glycolysis [9].

Literatures suggested that there is no report available to explain the roles of $\mathrm{LDH}$ and $\mathrm{MDH}$ and their behaviour of corresponding isozymes in different tissues of the Eri silkworm species particularly under low temperature stress. Therefore, the present study was envisaged to investigate the impact of low temperature $\left(10^{\circ} \mathrm{C} \pm 1^{\circ} \mathrm{C}\right)$ exposure for different time durations on the levels of $\mathrm{LDH}$ and $\mathrm{MDH}$ activity in the Indian silk producing insect, Eri silkworm. The present work also illustrated the perturbations in the behaviour of isozymes of $\mathrm{LDH}$ and $\mathrm{MDH}$ from different tissues of Eri silkworm insect exposed to low temperature using native-polyacrylamide gel electrophoresis (nativePAGE) [9-12].

We focused on changes in the behaviour of different isozymes of $\mathrm{LDH}$ and $\mathrm{MDH}$ and total protein content in silkworm, Philosamia ricini. For the first time, we studied the changes in activity pattern of energy metabolizing enzymes due to the exposure of low temperature in vivo. In this study, the effects of exposure of the silkworm to the low temperature on the levels of biochemical, and physiological indices have been investigated. This study provides evidence that low temperature exposure may induce acclimation in eri silkworm.

\section{Materials and methods}

\section{Animals}

The Eri silkworm, Philosamia ricini used in all the experiments is a continuously breeding lepidopteran. This insect mainly feeds on castoroil-plant leaves. The life cycle of $P$. ricini passes through five instar stages. At the culmination of fifth instar stage, it spins silk cocoon and changes into the pupa [13]. Disease-free egg laying Eri silkworms were obtained from Mangaldoi Seri culture farm of Assam. The silkworms were reared at Sericulture/entomology laboratory, Department of Zoology, University of Allahabad, Allahabad, under recommended condition at $25 \pm 2^{\circ} \mathrm{C}$ temperature [14] $75 \pm 5 \%$ relative humidity and 12 h:12 h of Light: Dark photoperiod. The larvae were fed with Ricinus communis (castor) leaves harvested from the garden of Department of Botany, University of Allahabad campus. The fifth instar larvae were reared in isolated Petri dishes and used for the study. The standard rearing methods were adopted as recommended by Sarkar. The leaves were exposed to the low temperature and fed ad libitum. All the experiments were performed three times in triplicates (50 larvae per replication).

\section{Reagents and chemicals}

Oxaloacetate, acrylamide, N,N'-Methylenebisacrylamide, Ammonium Persulfate (APS), glycine, N,N,N',N'-Tetramethylethylenediamine (TEMED), bromophenol blue and sodium bicarbonate were purchased from Sigma-Aldrich. Potassium chloride $(\mathrm{KCl})$, sodium pyruvate, nicotinamide adenine dinucleotide (NADH), tris base, Ethylene Diamine Tetra Acetic acid (EDTA) was purchased from E. Merck, Darmstadt, Germany. Bovine serum albumin, were purchased from Loba Chemie Pvt. Ltd. Sucrose, sodium potassium-tartrate, n-butanol, boric acid, sodium chloride $(\mathrm{NaCl})$, calcium chloride $\left(\mathrm{CaCl}_{2}\right)$, FolinCiocalteu reagent (FCR), copper sulphate $\left(\mathrm{CuSO}_{4}\right)$ and sodium hydroxide $(\mathrm{NaOH})$ were purchased from Sisco Research Laboratory Pvt. Ltd, Mumbai, India. Hydrochloric acid $(\mathrm{HCl})$ was from Qualigens Fine Chemicals Pvt. Ltd. India.

\section{Exposure to low temperature}

The newly hatched larvae of Eri silkworm were reared on fresh leaves of castor-oil-plant (Ricinus communis). The fifth instar larvae of Eri silkworm insect were divided into 4 groups; each containing an equal number (50) of larvae in plastic trays. One of the groups was served as a control (reared at $25 \pm 2^{\circ} \mathrm{C}$ ) and the other three were exposed to low temperature $\left(10 \pm 1^{\circ} \mathrm{C}\right)$ for varying exposure durations (2, 4 and 7 days).

\section{Preparation of cell-free extract from the homogenates of dif-} ferent tissues (silk glands and fat body tissues)

The fifth instar larvae of Eri silkworm insect were dissected in icecold Bodenstein's Ringer solution. Their silk glands and fat body tissues were excised out [13]. The homogenates $(20 \% \mathrm{w} / \mathrm{v})$ of tissues were prepared in $50 \mathrm{mM}$ Tris- $\mathrm{HCl}$ buffer $(\mathrm{pH}$ 7.0) using Potter-Elvehjam homogenizer with teflon coated pestle under ice cold condition. The cell free extract was prepared using cooling centrifuge. The homogenates were centrifuged at $9000 \mathrm{~g}$ and supernatants were used as cell free extract for further biochemical estimations. For isozyme analysis, another set of homogenates $(20 \% \mathrm{w} / \mathrm{v})$ were prepared in sucrose buffer containing $0.2 \mathrm{M}$ sucrose, $10 \mathrm{mM}$ EDTA, and $0.2 \mathrm{M}$ Tris $\mathrm{HCl}, \mathrm{pH}$ 7.0.

\section{Estimation of total protein}

The protein contents of cell free extracts in different tissues from Eri silkworm insect was determined according to the method of Lowry et al. $[15,16]$ using bovine serum albumin (BSA) as standard.

\section{Assay for the activity of enzymes}

The activities of LDH and MDH were measured by NADHlinked optical assay following the method of Horecker and Kornberg (1948). In case of $\mathrm{LDH}$, sodium pyruvate $(0.5 \mathrm{mM})$ was used as substrate whereas in case of $\mathrm{MDH}$, oxaloacetate $(0.6 \mathrm{mM})$ served as substrate. The spectrophotometric measurements were done using ELICO SL 164 UVD model double beam spectrophotometer using quartz cuvette $(1.0 \mathrm{~cm}$ light path length) against enzyme blank at room temperature $\left(28 \pm 2^{\circ} \mathrm{C}\right)$. The measurements were made in duplicate in each tissue homogenate. The reaction velocity is determined by decreasing absorbance resulting from oxidation of NADH at $340 \mathrm{~nm}$. One unit of enzyme activity causes the oxidation of one micromole of $\mathrm{NADH}$ per minute at $25^{\circ} \mathrm{C}$; $\mathrm{pH} 7.4$.

\section{Native-polyacrylamide gel electrophoresis (native-PAGE) and activity staining of isozymes}

The activity staining of isozymes from different tissues from Eri silkworm insect exposed to low temperature, were analyzed by nativepolyacrylamide gel electrophoresis (native-PAGE) [11,16]. Isozyme variations were investigated using equal amount of proteins from different samples loaded to $7 \%$ polyacrylamide gel and resolved in cold for $2 \mathrm{~h}$ [17]. The native PAGE gels were conducted at constant voltage $(150 \mathrm{~V})$ in Tris-Borate-EDTA (TBE) buffer $(89 \mathrm{mM}$ Tris, $89 \mathrm{mM}$ boric acid, $2 \mathrm{mM}$ EDTA, $\mathrm{pH}$ 8.6). The isozyme bands in the gel were visualized using activity staining methods of Ayala.

\section{Statistical analysis}

Each assay was replicated four times. Values were expressed as mean \pm SE of replicates and Student's t-test was applied to locate significant $(\mathrm{p}<0.05)$ differences between treated and control groups. 
Citation: Singh A, Gupta VK, Siddiqi NJ, Tiwari S, Gopesh A, et al. (2017) Time Course Studies on Impact of Low Temperature Exposure on the Levels of Protein and Enzymes in Fifth Instar Larvae of Eri Silkworm, Philosamia ricini (Lepidoptera: satuniidae). Biochem Anal Biochem 6: 321. doi: $10.4172 / 2161-1009.1000321$

Page 3 of 6

\begin{tabular}{|l|l|l|l|}
\hline \multirow{2}{*}{ Tissues } & Control $(\mathbf{m g} / \mathbf{g}$ wet weight of tissue) & \multicolumn{3}{|l|}{ Experimental (mg/g wet weight of tissue) } \\
\cline { 2 - 4 } & 0 Day & 2 Days & 4 Days \\
\hline Haemolymph & $15.1 \pm 0.29^{\mathrm{a}}$ & $17.2 \pm 0.31^{\mathrm{a}}(+13.9)$ & $20.4 \pm 0.18^{\mathrm{a}}(+35.1)$ \\
\hline Silk gland & $108.0 \pm 0.70$ & $95.5 \pm 0.34(-11.5)$ & $86.2 \pm 0.32^{\mathrm{b}}(-20.2)$ \\
\hline Fat body tissues & $92.0 \pm 0.31$ & $82.6 \pm 0.16(-10.2)$ & $74.5 \pm 0.17^{\mathrm{b}}(-19.0)$ \\
\hline
\end{tabular}

P. ricini $5^{\text {th }}$ instar larvae was exposed for seven days at $10 \pm 1^{\circ} \mathrm{C}$ for the experimental set whereas the control group insects were reared at $25 \pm 2^{\circ} \mathrm{C}$. The total protein content was estimated using procedures as described in materials and methods. The values presented in the parentheses indicate the percent increase $(+)$ or decrease

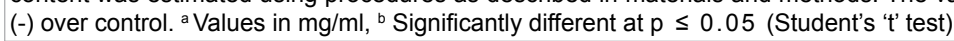

Table 1: Effect of low temperature $\left(10 \pm 1^{\circ} \mathrm{C}\right)$ exposure on the levels of protein content in three major tissues of $5^{\text {th }}$ instar larvae of $P$. ricini exposed for different days.

\begin{tabular}{|l|l|l|l|}
\hline \multirow{2}{*}{ Enzymes } & Control (U/mg protein) & \multicolumn{3}{|l|}{ Experimental (U/mg protein) } \\
\hline & 0 Day & 2 Days & 4 Days \\
\hline aMDH & $11.7 \pm 0.08$ & $9.8 \pm 0.06(-16.2)$ & $8.2 \pm 0.09(-29.9)$ \\
\hline aLDH & $7.9 \pm 0.3$ & $5.2 \pm 0.12(-34.2)$ & $7.3 \pm 0.06^{\mathrm{b}}(-37.6)$ \\
\hline
\end{tabular}

P. ricini $5^{\text {th }}$ instar larvae were exposed for 7 days at $10 \pm 1^{\circ} \mathrm{C}$ for experimental set whereas control group insects were reared at $25 \pm 2{ }^{\circ} \mathrm{C}$. One unit of enzyme activity has been defined as the amount of enzyme required to catalyze the transformation of one $\mu$ mol of substrate or the formation of one $\mu$ mol of product per min under specified

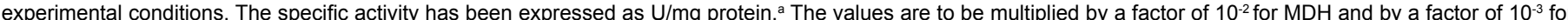
$\mathrm{LDH}$. The results represent the average values of three independent experiments. The values in parentheses indicate percent increase (+) or decrease (-) over control. ${ }^{b}$ Significantly different at $p \leq 0.05$ (Student's ' $t$ ' test).

Table 2: Effect of low temperature $\left(10 \pm 1^{\circ} \mathrm{C}\right)$ exposure on specific activities of MDH and LDH in haemolymph of $5^{\text {th }}$ instar larvae of $P$. ricini exposed for different days

\begin{tabular}{|c|c|c|c|c|}
\hline \multirow{2}{*}{ Enzymes } & \multirow{2}{*}{\begin{tabular}{|l} 
Control (U/mg protein) \\
0 Day
\end{tabular}} & \multicolumn{3}{|c|}{ Experimental (U/mg protein) } \\
\hline & & 2 Days & 4 Days & 7 Days \\
\hline aMDH & $7.9 \pm 0.06$ & $8.7 \pm 0.15(+10.1)$ & $9.8 \pm 0.12(+24.0)$ & $11.5 \pm 0.17(+45.6)$ \\
\hline aLDH & $1.8 \pm 0.12$ & $1.6 \pm 0.06(+11.1)$ & $1.4 \pm 0.08(+22.2)$ & $1.2 \pm 0.09^{b}(-33.3)$ \\
\hline
\end{tabular}

P. ricini $5^{\text {th }}$ instar larvae were exposed upto seven days at $10 \pm 1^{\circ} \mathrm{Cfor} \mathrm{experimental} \mathrm{set} \mathrm{whereas} \mathrm{the} \mathrm{control} \mathrm{group} \mathrm{insects} \mathrm{were} \mathrm{reared} \mathrm{at} 25 \pm 2^{\circ} \mathrm{C}$. One unit $(\mathrm{U})$ of enzyme activity has been defined as the amount of enzyme required to catalyze the transformation of one $\mu$ mol substrate or the formation of one $\mu$ mol product per min under specified experimental conditions. The specific activity has been expressed as $\mathrm{U} / \mathrm{mg}$ protein a The values are to be multiplied by a factor of $10^{-2}$ for $\mathrm{MDH}$ and by a factor of $10^{-3}$ for LDH. The results represent average values of three independent experiments. The values in parentheses indicate percent increase (+) or decrease $(-)$ over control. b Significantly different at $\mathrm{p} \leq 0.05$ (Student's ' $\mathrm{t}$ ' test).

Table 3: Effect of low temperature $\left(10 \pm 1^{\circ} \mathrm{C}\right)$ exposure on the levels of specific activities of MDH and LDH in silk gland of $5^{\text {th }}$ instar larvae of $P$. ricini exposed for different days

\section{Results}

\section{Effect of low temperature on the level of total protein content in different tissues of eri silkworm (Philosamia ricini)}

The exposure of low temperature results is shown in Table 1, on the levels of protein content in three different organs of Eri silkworm insect larvae. The maximum protein content was observed in silk gland (108 $\mathrm{mg} / \mathrm{g}$ wet weight of the tissue) followed by fat body tissues $(92 \mathrm{mg} / \mathrm{g}$ wet weight of the tissue) and haemolymph $(15 \mathrm{mg} / \mathrm{g}$ wet weight of the tissue) in control. After exposure to low temperature, the insect larvae haemolymph exhibited elevation in the level of protein content $(14 \%$ to $69 \%$ ) over different periods of exposure (2 to 7 days). However, a reverse pattern was observed in the silk gland and fat body tissues. The low temperature stress caused decrease in protein content of silk gland and fat body tissues to almost similar extent and the values being $12 \%$ to $32 \%$ and $10 \%$ to $30 \%$ in silk gland and fat body tissues, respectively (Table 1). The impact of low temperature stress on the levels of protein content was more pronounced at higher exposure duration (7 days) than that at lower exposure durations ( 2 or 4 days).

Effect of low temperature on the activity level of energy metabolism enzymes (LDH and MDH) in different tissues of eri silkworm (Philosamia ricini)

While comparing the LDH activity with control tissues, haemolymph displayed maximum specific activity $(7.9 \mathrm{U} / \mathrm{mg}$ protein, Table 2) followed by fat body tissues $(3.0 \mathrm{U} / \mathrm{mg}$ protein) and silk gland (1.8 U/mg protein, Table 3). However, the activity of $\mathrm{MDH}$ in the control tissues was recorded to be maximum in the fat body tissues (12 $\mathrm{U} / \mathrm{mg}$ protein, Table 4) followed by haemolymph (11.7 U/mg protein,
Table 2$)$ and silk gland $(7.9 \mathrm{U} / \mathrm{mg}$ protein, Table 3$)$. The activity of $\mathrm{MDH}$ in fat body tissues (Table 4) and haemolymph (Table 2) of control Eri silkworm insect larvae appeared to be almost similar. When the insect larvae were exposed to low temperature, the activities of LDH and $\mathrm{MDH}$ exhibited significant $(\mathrm{p} \leq 0.05$ ) decrease of $34 \%$ to $65 \%$ and $16 \%$ to $38 \%$, respectively in haemolymph (Table 2 ). The impact of low temperature stress on the levels of the enzymes activity was found to be higher at maximum exposure duration ( 7 days) than the others ( 2 or 4 days).

Similar experiments were conducted in silk gland of Eri silkworm insect larvae. In this, the low temperature stress resulted into drastic increase $(10 \%$ to $46 \%)$ in $\mathrm{MDH}$ activity, whereas the activity of $\mathrm{LDH}$ displayed a different behaviour (Table 3 ). The trend was not uniform over different exposure durations (2, 4 and 7 days). The activity of LDH increased ( $11 \%$ to $22 \%)$ upto $4^{\text {th }}$ day and then after it significantly ( $\mathrm{p} \leq 0.05)$ decreased (33\%) as compared to control due to further increase in exposure duration ( $7^{\text {th }}$ day) (Table 3 ). Thus, the effect of low temperature exposure on the activity of LDH from silk gland of Eri silkworm insect larvae appeared to be biphasic in nature.

The results of low temperature exposure on the activity levels of these two enzymes ( $\mathrm{LDH}$ and $\mathrm{MDH}$ ) from fat body tissues of $5^{\text {th }}$ instar larvae of Eri silkworm insect are shown in Table 4. The data reflected that the low temperature stress induced significant ( $\mathrm{p} \leq$ 0.05 ) elevations in activity of $\mathrm{LDH}(40 \%$ to $23 \%)$ and $\mathrm{MDH}$ (50\% to $170 \%)$ from fat body tissues of Eri silkworm insect larvae over varying periods of exposure. Rise in the activity levels of these enzymes were found to be consistently enhanced up to $7^{\text {th }}$ day of exposure (Table 4). The data also demonstrated that percent increase in MDH activity was much higher than $\mathrm{LDH}$ activity due to low temperature stress along 
Citation: Singh A, Gupta VK, Siddiqi NJ, Tiwari S, Gopesh A, et al. (2017) Time Course Studies on Impact of Low Temperature Exposure on the Levels of Protein and Enzymes in Fifth Instar Larvae of Eri Silkworm, Philosamia ricini (Lepidoptera: satuniidae). Biochem Anal Biochem 6: 321. doi: $10.4172 / 2161-1009.1000321$

Page 4 of 6

\begin{tabular}{|c|c|c|c|c|}
\hline \multirow[b]{2}{*}{ Enzymes } & \multirow{2}{*}{$\begin{array}{l}\text { Control (U/mg protein) } \\
\text { O Day }\end{array}$} & \multicolumn{3}{|c|}{ Experimental (U/mg protein) } \\
\hline & & 2 Days & 4 Days & 7 Days \\
\hline${ }^{\mathrm{a}} \mathrm{MDH}$ & $12.1 \pm 0.17$ & $18.2 \pm 0.52(+50.4)$ & $26.4 \pm 0.64(+118.2)$ & $32.7 \pm 0.7^{b}(+170.2)$ \\
\hline a $\mathrm{LDH}$ & $3.0 \pm 0.12$ & $4.2 \pm 0.17(+40.0)$ & $5.6 \pm 0.15(+86.7)$ & $6.7 \pm 0.23(+123.3)$ \\
\hline
\end{tabular}

P. ricini $5^{\text {th }}$ instar larvae were acclimated for seven days at $10 \pm 1{ }^{\circ} \mathrm{C}$ for the experimental set whereas the control group insects were reared at $25 \pm 2{ }^{\circ} \mathrm{C}$. One unit $(\mathrm{U})$ of enzyme activity has been defined as the amount of enzyme required to catalyze the transformation of one $\mu$ mol substrate or the formation of one $\mu$ mol product per min under specified experimental conditions. The specific activity has been expressed as $\mathrm{U} / \mathrm{mg}$ protein. ${ }^{\text {a }}$ the values are to be multiplied by a factor of $10^{-2}$ for $\mathrm{MDH}$ and by a factor of $10^{-3}$ for $\mathrm{LDH}$. The results represent average values of three independent experiments. The values in parentheses indicate percent increase $(+)$ or decrease $(-)$ over control. ${ }^{b}$ significantly different at $p \leq 0.05$ (Student's ' $t$ ' test)

Table 4: Effect of exposure to low temperature $\left(10 \pm 1^{\circ} \mathrm{C}\right)$ on the levels of specific activities of MDH and LDH in fat body tissues of $5^{\text {th }}$ instar larvae of $P$. ricini exposed for different days.

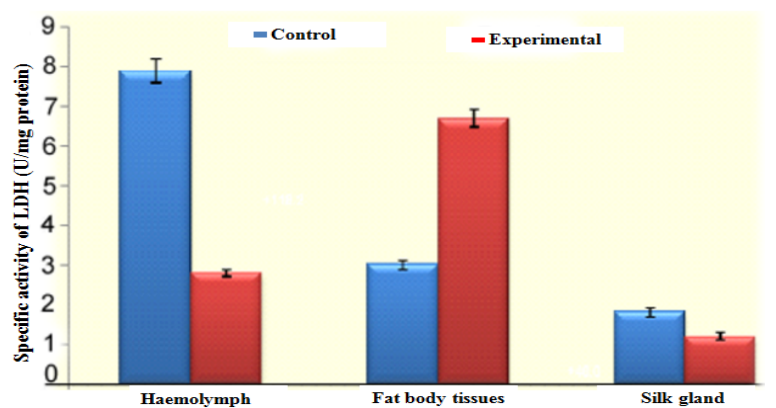

Figure 1: Effect of low temperature $\left(10 \pm 1^{\circ} \mathrm{C}\right)$ exposure on the levels of LDH activity in three different tissues of $5^{\text {th }}$ instar larvae of $P$. ricini exposed for 7 days. The histogram was prepared with the data presented into Tables 1, 2 and 3 for the effect of low temperature exposure on the levels of LDH activity in different tissues of $5^{\text {th }}$ instar larvae of $P$. ricini for maximum duration (7 days) of exposure for organwise comparison.

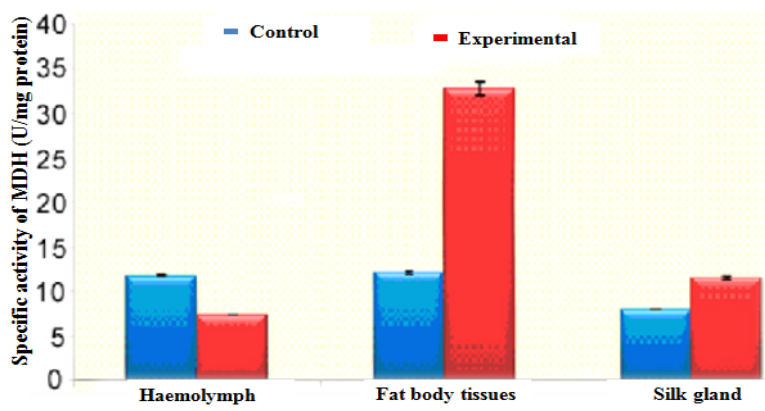

Figure 2: Effect of low temperature $\left(10 \pm 1^{\circ} \mathrm{C}\right)$ exposure on the levels of MDH activity in three different tissues of $5^{\text {th }}$ instar larvae of $P$. ricini exposed for 7 days. The histogram was prepared with the data presented in Tables 1, 2 and 3 for organwise comparison upto maximum period (7 days) of exposure.

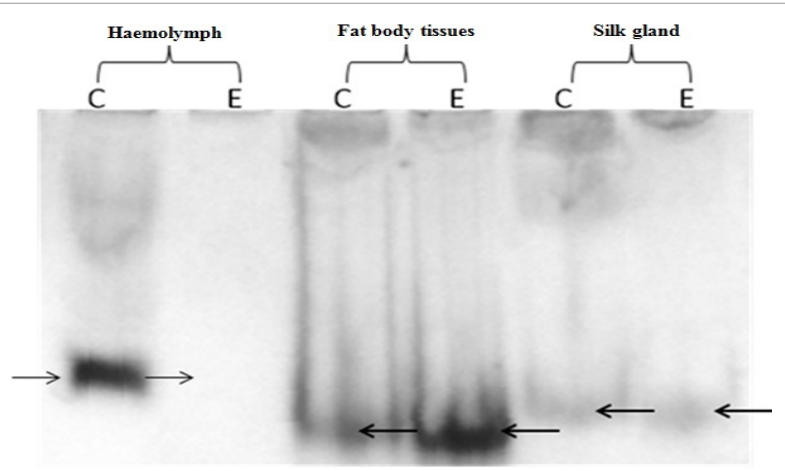

Figure 3: Isozyme activity pattern of LDH in $5^{\text {th }}$ instar $P$. ricini larvae exposed up to 7 days. $\mathrm{C}=\mathrm{C}$ Control, reared at temperature $\left(25 \pm 2^{\circ} \mathrm{C}\right)$, E=Experimental, exposed at temperature $\left(10 \pm 1^{\circ} \mathrm{C}\right)$ for 7 days. The arrow $(\rightarrow)$ represents the position of isozyme bands. all of three different exposure durations. Similarly, the effect of low temperature exposure in the haemolymph and fat body tissues of Eri silkworm insect larvae were also found to be dependent on period of exposure.

Since the impact of low temperature stress on the activity levels of $\mathrm{LDH}$ and $\mathrm{MDH}$ in different tissues of Eri silkworm insect larvae was found to be highest after the maximum exposure duration (7 days), the data for $\mathrm{LDH}$ and $\mathrm{MDH}$ from Tables 2, 3 and 4 for this maximum exposure duration (7 days) period was presented in Figures 1 and 2 showing the marked perturbations in all the three organs of Eri silkworm insect larvae as compared to control. The data presented in Figure 1 indicated that haemolymph and silk glands exhibited decrease in LDH activity by $65 \%$ and $33 \%$, respectively whereas fat body tissues registered sharp increase (123\%) in $\mathrm{LDH}$ activity due to low temperature stress after 7 days of exposure. On the other hand, the data presented in Figure 2 demonstrated that the activity of $\mathrm{MDH}$ significantly increased in silk gland (46\%) and fat body tissues (170\%) whereas significant decrease by $38 \%$ was recorded in haemolymph due to low temperature stress after 7 days of exposure.

\section{Effect of low temperature on the expression level of energy metabolism enzymes (LDH and MDH) in different tissues of eri silkworm (Philosamia ricini)}

Results from the effect of low temperature stress on the isozymes expression of $\mathrm{LDH}$ and $\mathrm{MDH}$ in Eri silkworm insect larvae after 7 days of exposure are presented in Figures 3 and 4, respectively. As it is evident from the Figures 3 and 4 of native-PAGE, only one isozyme band was obtained from each of these cases. The comparative isozyme pattern of LDH from all the three major tissues of Eri silkworm insect larvae as shown in Figure 3 indicated maximum activity of LDH in haemolymph of control group (lane C) which could not be detected in gel after low temperature exposure (Lane E). The silk gland tissues showed the lower LDH activity in low temperature exposed group (lane E) as compared to that of the control group (Lane C). Interestingly, the isozyme pattern of LDH in fat body tissues was unique in a manner that the low temperature stress caused significant increase in the intensity of LDH isozyme band (lane E) as compared to control (lane C). The LDH isozyme bands from silk glands and fat body tissues migrated longer as compared to that of haemolymph. The order of migration of LDH isozymes in tissues tested was as following: haemolymph $>$ silk gland $>$ fat body tissues. However, the gel pattern of MDH isozyme activity (Figure 4) reflected rise in the silk gland and fat body tissues of the Eri silkworm insect larvae exposed with low temperature (lane E) when compared with that of control (lane C). In contrast, the activity of $\mathrm{MDH}$ isozyme from haemolymph was observed to be diminished, due to exposure of low temperature (lane E). Similar to the migration of LDH isozyme bands, the distance traveled by the $\mathrm{MDH}$ isozyme bands from silk gland and fat body tissues were more than the MDH isozyme from haemolymph (Figure 4). The MDH isozyme migration order of bands 

of Protein and Enzymes in Fifth Instar Larvae of Eri Silkworm, Philosamia ricini (Lepidoptera: satuniidae). Biochem Anal Biochem 6: 321. doi: $10.4172 / 2161-1009.1000321$

Page 5 of 6

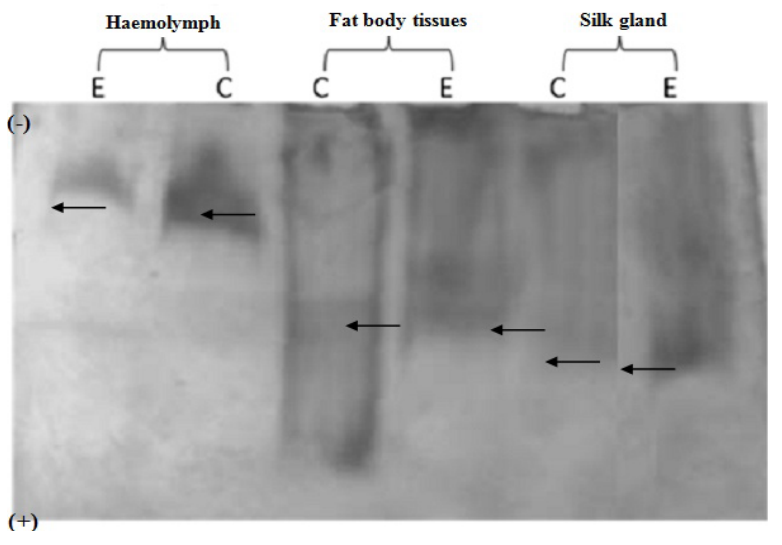

Figure 4: Isozyme activity pattern of $\mathrm{MDH}$ in $5^{\text {th }}$ instar $P$. ricini larvae exposed for 7 days. $\mathrm{C}=$ Control, reared at temperature $\left(25 \pm 2^{\circ} \mathrm{C}\right), \mathrm{E}=$ Experimental, exposed at temperature $\left(10 \pm 1^{\circ} \mathrm{C}\right)$ up to 7 days. The arrow $(\rightarrow)$ represents the position of isozyme bands.

in these tissues was as following: haemolymph $>$ fat body tissues $>$ silk gland.

\section{Discussion}

The impact of low temperature $\left(10 \pm 1^{\circ} \mathrm{C}\right)$ exposure to $5^{\text {th }}$ instar larvae of Eri silkworm, P. ricini, were resulted into some changes in its biochemical constituents, so that it can cope up with such harsh conditions. Here, the emphasis was given to evaluate the impact of low temperature exposure on activity levels of two enzymes (LDH and $\mathrm{MDH}$ ) which are involved in energy metabolism of Eri silkworm insect larvae. The results shown in Tables 1-4, indicated that low temperature stress affected the levels of total protein content and activity of enzymes ( $\mathrm{LDH}$ and $\mathrm{MDH}$ ) in different tissues of Eri silkworm insect larvae.

Earlier it has been reported that some organisms, when subjected to low temperature stress, exhibited a marked alteration in their metabolism by changing the levels of certain enzyme(s) activity $[3,5,18,19]$. In present study, we have shown that the level of total protein content increases consistently in hemolymph of Eri silkworm insect larvae due to low temperature stress over increasing period of exposure. It is important to note that the level of protein gradually decreases over increasing exposure period in silk gland as well as in fat body tissues. Since, haemolymph of the insects acts as a reservoir of various metabolites, from different organs [20]. It is quite likely that the decreasing pattern of total protein content in silk gland and fat body tissues may be due to the mobilization of the proteins from these two organs to haemolymph and/or utilization of protein for generation of energy, to survive and mitigate adverse impact of low temperature exposure. The over wintering insects have to contend with osmotic stress [21,22]. It has been reported that the rapid cold-hardening is associated with increase in concentration of some metabolites and osmolality of haemolymph [23]. While studying low temperature stress tolerance in Drosophila melanogaster, Misener et al., have explained their results in the haemolymph of low temperature stressed insect in similar manner [24].

In present study, the activities of $\mathrm{LDH}$ and $\mathrm{MDH}$ were expressed differently in different tissues of Eri silkworm insect larvae, when subjected to low temperature exposure for 2, 4 and 7 days. The activity levels of these enzymes decreased in haemolymph with maximum reduction in $\mathrm{LDH}$ activity as compared to $\mathrm{MDH}$, thereby showing the energy metabolism system in haemolymph of Eri silkworm insect larvae ceases to support physiological activities at low temperature. In fat body tissues their activities sharply increased across all exposure periods. The increase in LDH activity have been reported to be associated with an increase in anaerobic catabolism leading to production of ethanol, lactate and alanine as end-products in $C$. riparius larvae when exposed to anoxia condition $[3,9,25]$.

The present study indicated that during low temperature exposure, the extent of elevation in MDH activity was significantly higher than $\mathrm{LDH}$ at all the three durations. These findings suggested that under low temperature stress condition, the energy metabolism system in fat body tissues may get activated to support the functions of Eri silkworm insect larvae by supplying required amount of energy. Though, in silk gland Eri silkworm insect larvae, the activity of $\mathrm{MDH}$ increased consistently with increasing exposure durations, the extent of elevation in MDH activity was not as high as it was recorded in fat body tissues. The results suggested that under low temperature exposure condition, fat body tissues served as a primary energy producing organ. Just like other organisms, these findings also indicated that the low temperature exposure induce aerobic respiration with greater extent as compared to anaerobic respiration, thereby suggesting the main energy supplying process in Eri silkworm insect larvae, while anaerobic respiration may play auxiliary roles in energy metabolism as reported in T. granosa [6].

Insects have been reported to exploit several biochemical mechanisms to survive during low temperature stress conditions [26,27]. The increased MDH activities of $P$. ricini larvae (present investigation) suggested that this enzyme contribute to reducing power in form of NADH in fat body tissues and silk gland due to low temperature exposure, which may also lead to anoxia condition $[9,26,27]$. Under these conditions, pyruvate produced by the oxidative decarboxylation of malate and converted to alanine in C. riparius larvae exposed to anoxia, a consequence of low temperature stress [3].

The expression patterns of LDH and MDH isozymes from different tissues of Eri silkworm insect larvae revealed greatly influenced by low temperature exposure. The control (C) and experimental (E) lanes corresponds to the activity values indicated in Tables 2-4. In native-PAGE gel, the migration of isozyme bands of $\mathrm{LDH}$ and $\mathrm{MDH}$ from haemolymph was relatively smaller than silk gland and fat body tissues. These findings suggest that $\mathrm{LDH}$ and $\mathrm{MDH}$ may have different molecular composition and/or conformation in haemolymph as well as in other tissues of Eri silkworm insect larvae tested. However, a detailed study is required to characterize different molecular forms of these isozymes from different tissues of Eri silkworm insect larvae before reaching to any definitive conclusion.

\section{Conclusion}

The $5^{\text {th }}$ instar larvae of Eri silkworm $P$. ricini displayed accumulation of protein content in haemolymph and depletion of the same in silk gland and fat body tissues due to low temperature stress. Under this condition, fat body tissues emerged as the main energy supplying organ of Eri silkworm insect larvae, thus supporting their survival under low temperature stress. In low temperature stressed Eri silkworm insect larvae, aerobic respiration was augmented to act as main energy supplying pathway. LDH and MDH displayed the presence of only one isozyme in all tissues of Eri silkworm insect larvae tested. The behaviour of the $\mathrm{LDH}$ and $\mathrm{MDH}$ isozymes towards low temperature stress response and migration varied in different tissues of Eri silkworm insect larvae. The molecular forms of $\mathrm{LDH}$ and $\mathrm{MDH}$ present in haemolymph seem to be distinct from rest of the tissues. The alterations in biochemical characteristics of these biomolecules may be attributed 
Citation: Singh A, Gupta VK, Siddiqi NJ, Tiwari S, Gopesh A, et al. (2017) Time Course Studies on Impact of Low Temperature Exposure on the Levels of Protein and Enzymes in Fifth Instar Larvae of Eri Silkworm, Philosamia ricini (Lepidoptera: satuniidae). Biochem Anal Biochem 6: 321. doi: 10.4172/2161-1009.1000321

Page 6 of 6

to the acclimation of low temperature in $5^{\text {th }}$ instar larvae of Eri silkworm insect, $P$. ricini.

\section{Acknowledgments}

The authors AS, VKG and ST gratefully acknowledge to the University Grants Commission (UGC)-New Delhi, India for providing financial support in the form of Research Fellowships. NJS would like to thank the Research Center, Center for Scientific and Medical Female Colleges, King Saud University, Riyadh for the financial support.

\section{References}

1. Zhao Z (1997) Progress in the research on mechanism of insect cold-hardiness Insect Sci 4: 265-276.

2. Forcella M, Berra E, Giacchini R, Parenti P (2007) Antioxidant defenses preserve membrane transport activity in Chironomus riparius larvae exposed to anoxia. Archi Insect Biochem Physiol 65: 181-194.

3. Duman JD, Wu DW, Xu L, Tursman D, Olsen TM (1991) Adaptations of insects to subzero temperatures. The Quart Rev Biol 66: 387-410.

4. Su XR, Lv ZM, Li TW, Liu ZM, Paul KC (2007) Analysis of isozymes related to energy metabolism of adult Tegillarca granosa. Chin J Agri Biotech 4: 163-166.

5. Panepucci L, Fernandes MN, Sanches JR, Rantin FT (2000) Changes in lactate dehydrogenase and malate dehydrogenase activities during hypoxic and after temperature acclimation in the armored fish, Rhinelepis strigosa (Siluriformes, Loricariidae). Revi Brasil de Biol 60: 353-360.

6. Duncan WP, Marcon JL (2009) Enzymes of energy metabolism in hatchlings of amazonian fresh water turtles (Testudines, Podocnemididae). Braz J Biol 69: 319-325

7. Suarez RK, Darveau CA, Welch KC Jr, OBrien DM, Roubik DW, et al. (2005) Energy metabolism in orchid bee flight muscles: carbohydrate fuels all. J Experi Biol 208: 3573-3579.

8. Zink MW, Shaw DA (1968) Regulation of malic isozymes and malic dehydrogenase in Neurospora crassa. Canad J Microbiol 14: 907-912.

9. Hopkinson DA, Harris H (1976) Handbook of enzyme electrophoresis in human genetics. North Holland, Amsterdam.

10. Hu NS, Wan XG (1985) The technology of isozymes and its application Human: Sci Tech Press pp. 70-85.

11. Mahamat H, Hassanali A, Morgan H, Mutinga MJ, Mihok S, et al. (1992) Isozymes analysis of kenyan Phlebotomine sandflies (Diptera: Psychodidae) by isoelectric focusing (IEF) on pharmacia phast system. Bioche Syste Ecol 20: 593-596

12. Kumar R, Elangovan V (2010) Assessment of the volumetric attributes of er silkworm (Philosamia ricini) reared on different host plants. I.J.S.N 1: 156-160.

13. Ringer $S$ (1882) Concerning the influence exerted by each of the constituents of the blood on the contraction of the ventricle. The J physiol 3: 380-393.

14. Matsubara F, Sang Q, Sugimori H, Ishiko S, Sumida M, et al. (1988) New method of silkworm rearing on an artificial diet (two feedings throughout the larval period). J Seric Sci 57: 118e122.

15. Lowry OH, Rosebrough NJ, Farr AL, Randall RJ (1951) Protein measurement with Folin-Phenol reagent. The J Biol Chem 193: 266-275.

16. Lin J, Somero GN (1995) Temperature-dependent changes in expression of thermo stable and thermolabile isozymes of cytosolic malate dehydrogenase in the eurythermal goby fish Gillichthys mirabilis. Physiol Zool 68: 114-128.

17. Gopalkrishanan A, Muneer PMA, Thomas PC, Lal KK, Mohindra V, et al. (2006) Identification of polymorphic allozyme markers for population structure analysis in Horabagrus brachysoma (Gunther, 1864). Ind J Fishe 53: 253-261.

18. Singh A, Jaiswa SK, Sharma B (2013) Low temperature stress causing biomolecular perturbations in insects with special reference to silkworms. $J$ Biochem Res 1: 26-35.

19. Singh A, Sharma RK, Sharma B (2010) Low temperature induced alteration in certain biochemical constituents of $5^{\text {th }}$ instar larvae of Philosamia ricin (Lepidoptera: Satunidae). Open Access Insect Physiol 2: 1-6.

20. Scaraffia PY, Wells MA (2003) Proline can be utilized as an energy substrate during flight of Aedes aegypti females. J Insect Physiol 49: 591-601.

21. Singh A, Sharma B (2016) Association of low temperature treatment induced protein expression in silkworm, Philosamia ricini (lepidoptera: satunidae) to acclimation. Int J Scien Inno Res 4: 19-24.

22. Storey KB (1983) Metabolism and bound water in over wintering insects. Cryobio 20: $365-379$

23. Chen CP, Denlinger DL, Lee RE Jr (1987) Cold-shock injury and rapid cold hardening in the lesh fly, Sarcophaga crassipalpis. Physiol Zool 60: 297-304

24. Misener SR, Chen CP, Walker VK (2001) Cold tolerance and praline metabolic gene expression in Drosophila melanogaster. J Ins Physiol 47: 393-400.

25. Hermes-Lima M, Storey JM, Storey KB (2001) Antioxidant defenses and anima adaptation to oxygen availability during environmental stress. Cell Mol Resp Stress 2: 263-287.

26. Berra E, Forcella M, Giacchini R, Marziali L, Rossaro B, et al. (2004) Evaluation of enzyme biomarkers in freshwater invertebrates from Taro and Ticino river, Italy. Annal de limnol 40: 169-180.

27. Feala JD, Coquin L, Zhou D, Haddad GG, Paternostro G, et al. (2009) Metabolism as means for hypoxic adaptation: metabolic profiling and flux balance analysis. BMC Syst. Biol 3: 91. 